\title{
Penerapan Sistem Penjualan Online pada Usaha Dagang Kusuma Bandung
}

\author{
Ricky Firmansyah ${ }^{1}$ \\ AMIK BSI Bandung, ricky.rym@bsi.ac.id \\ Phitsa Mauliana ${ }^{2}$ \\ AMIK BSI Bandung, phitsa.phu@bsi.ac.id \\ Nanang Hunaifi ${ }^{3}$ \\ AMIK BSI Bandung, nanang.nnu@bsi.ac.id \\ Wildan Wiguna ${ }^{4}$ \\ AMIK BSI Tasikmalaya, wildan.wgg@bsi.ac.id \\ R. Dewi Sulastriningsih ${ }^{5}$, \\ Universitas BSI Bandung, dewi.rwl@bsi.ac.id \\ Yunika Komalasari 6 \\ Universitas BSI Bandung, yunika.yui@bsi.ac.id
}

\begin{abstract}
Abstrak
Usaha Dagang Kusuma merupakan UMKM pemasok produk olahan hasil pertanian berupa minuman buah carica, jus terong belanda, kentang goreng dan fresh potatoes di Kota Bandung. Proses penjualan dan promosi UD. Kusuma sampai saat ini masih menggunakan cara yang konvensional, yaitu dengan menunggu pelanggan datang ke lokasi sehingga pelanggannya terbatas dan membutuhkan suatu cara untuk meningkatkan usahanya. Hasil pertanian yang cepat kadaluarsa dan rentan rusak membutuhkan cara pemasaran tersendiri untuk dapat sampai ke tangan konsumen. Bisnis toko online dapat membuka banyak kesempatan dalam menumbuhkan setiap usaha perusahaan, termasuk untuk bisnis UMKM yang menawarkan produk olahan hasil pertanian seperti UD. Kusuma. Pengabdian kepada masyarakat ini fokus kepada penerapan sistem penjualan online pada UD. Kusuma menggunakan website penjualan online yang dikembangkan dengan menggunakan Plug-in WooCommerce pada CMS WordPress dan MySQL sebagai Sistem Manajemen Basis Data. Hasil dari pengabdian kepada masyarakat ini adalah bahwa dengan adanya website ini, UD. Kusuma dapat memperluas pemasaran dan dapat menjual produk kepada pelanggan tanpa harus datang ke lokasi untuk saling bertemu. Dengan memanfaatkan teknologi informasi ini juga, memungkinkan UMKM untuk menjangkau pasar global, sehingga kesempatan untuk menembus ekspor sangatlah memungkinkan. UMKM sebagai salah satu jenis usaha kecil menengah di Indonesia sudah seharusnya menggunakan teknologi imformasi demi memajukan usahanya.
\end{abstract}

Kata Kunci: buah, e-commerce, pemasaran, pertanian, website 


\title{
JURNAL ABDIMAS UBJ
}

\begin{abstract}
Usaha Dagang Kusuma is a SMEs that supply of agricultural processed products likes carica fruit drink, Dutch eggplant juice, fries and fresh potatoes in Bandung. UD. Kusuma's sales and promotion process is still using the conventional way like waiting for customers to come to the location so their customers are limited and need a way to improve their business. Expired rapidly and fragile agricultural products require their own marketing methods to reach the hands of consumers. Online store business can open many opportunities in growing every business enterprise, including for UMKM business that offers products of agricultural products processed such as UD. Kusuma. This dedication of this community services is focuses on the implementation of online sales system at UD. Kusuma uses an online sales website developed by using the WooCommerce Plug-in on CMS WordPress and MySQL as a Database Management System. The result of community service is with this website, UD. Kusuma can expand marketing and can sell products to customers without having to come to a location to meet each other. By utilizing this information technology also, enabling SMEs to reach the global market, so the opportunity to penetrate the export is possible. SMEs as one type of small and medium enterprises in Indonesia are supposed to use imformasi technology in order to advance its business.
\end{abstract}

Keyword: agriculture, e-commerce, fruit, marketing, website

\section{Pendahuluan}

Usaha Dagang Kusuma (UD. Kusuma) merupakan UMKM pemasok produk olahan hasil pertanian berupa minuman buah carica, jus terong belanda, kentang goreng dan fresh potatoes yang mulai beroperasi pada tahun 2010. Proses penjualan dan promosi UD. Kusuma sampai saat ini menggunakan cara konvensional, yaitu dengan menunggu pelanggan datang ke lokasi. Promosi yang dilakukan selama ini adalah melalui selebaran atau brosur dan mengikuti pameran/ event-event tertentu untuk langsung menawarkan produk yang dijual. Hasil pertanian yang cepat kadaluarsa dan rentan rusak membutuhkan cara pemasaran tersendiri, untuk dapat sampai ke tangan konsumen (Yuantari, Kurniadi, \& Ngatindriatun, 2016). Bisnis toko online dapat membuka banyak kesempatan dalam menumbuhkan setiap usaha perusahaan, termasuk untuk bisnis UMKM yang menawarkan produk olahan hasil pertanian seperti UD. Kusuma (Sandy, 2016). Setiap UMKM memiliki peluang untuk menjual dan menyalurkan produk atau jasa miliknya dengan tidak bergantung pada lokasi dan lahan tempat yang luas untuk usaha (Sandy, 2016). Peran teknologi informasi (TI) terhadap bisnis yang semakin kuat dapat dilihiat dari penggunaan internet dan website oleh perusahaan saat ini yang sangat diperlukan (Nuryanti, 2013).

Saat ini, hampir seluruh masyarakat (terutama negara maju) telah terbiasa menggunakan web, karena sebagian besar jenis informasi dapat diperoleh. Teknologi informasi merupakan cara yang digunakan untuk membuat, menyimpan, mengubah, dan memanfaatkan setiap jenis informasi. Dengan memanfaatkan teknologi informasi ini, UMKM dapat memasuki pasar global. Penggunaan teknologi informasi dalam bisnis atau dikenal dengan istilah e-commerce bagi UMKM dapat 


\section{JURNAL ABDIMAS UBJ}

meningkatkan fleksibilitas produksi, memudahkan penyaluran kepada pelanggan dengan cepat untuk produk berupa perangkat lunak (software), mengirim dan menerima penawaran secara cepat dan efisien, serta mendukung transaksi segera tanpa menggunakan kertas. Pemanfaatan internet juga memungkinkan UMKM untuk menjangkau pasar global, sehingga kesempatan untuk menembus ekspor sangatlah memungkinkan. UMKM sebagai salah satu jenis usaha kecil menengah di Indonesia sudah seharusnya menggunakan teknologi imformasi demi memajukan usahanya (Nuryanti, 2013).

Berdasarkan kondisi di atas, pengabdian kepada masyarakat ini ini fokus kepada bagaimana menerapkan sistem penjualan online pada UD. Kusuma menggunakan website? Website penjualan online dikembangkan dengan menggunakan Plugin WooCommerce pada CMS WordPress dan MySQL sebagai Sistem Manajemen Basis Data (Database Manangement System, DBMS).

\section{Internet}

Internet awalnya merupakan kependekan dari inter-connection network. Namun kini, internet bukan merupakan singkatan lagi melaikan sebuah istilah yang memiliki pengertian sebuah jaringan komunikasi terbuka dengan skala global yang menghubungkan milyaran perangkat dan jaringan komputer dari berbagai tipe dan merek/vendor, yang menggunakan jenis komunikasi baik itu telepon, satelit dan sebagainya. Protokol yang digunakan untuk menghubungkan jaringan internet adalah TCP/IP. Dengan menggunakan protokol tersebut, semua perangkat keras juga perangkat lunak dengan tipe berbeda dapat terhubung (Firmansyah, 2018).

\section{E-Commerce}

E-Commerce dapat diartikan sebagai pedagangan secara elektronik, yaitu melalui internet. Defisini lain yaitu, E-commerce adalah suatu cara berbisnis dengan menggunakan teknologi elektronik yang mempertemukan konsumen dan masyarakat dengan perusahaan dan sebaliknya dalam bentuk transaksi virtual dan pertukaran atau penjualan barang, layanan, dan informasi secara virtual. Dalam ECommerce, penggunaan internet menjadi pilihan utama oleh kebanyakan orang dibandingkan dengan media elektronik lainnya karena kemudahan yang dimiliki internet, yaitu (Nimda, 2017):

a. Internet merupakan jaringan publik yang sangat luas, cepat dan mudah dalam mengaksesnya.

b. Internet menggunakan data electronik sebagai media pengiriman pesan atau data, sehingga pengiriman dan penerimaan baik dalam bentuk data elektronik analog maupun digital dapat dilakukan dengan mudah dan praktis.

Dengan adanya E-Commerce sebagai cara transaksi baru yang mudah dan cepat ini tentu saja akan menguntungkan berbagai pihak, baik pihak konsumen, maupun produsen dan penjual. Dengan memanfaatkan internet, proses jual beli bisa dilakukan dengan biaya dan waktu yang efisien. 


\section{JURNAL ABDIMAS UBJ}

\section{Website}

Website merupakan seluruh halaman web yang disimpan dalam hosting sebuah domain yang menyimpan data informasi. Website umumnya terdiri dari halaman web yang saling berhubungan dalam jumlah yang banyak. Keterhubungan masingmasing halaman web tersebut disebut hyperlink, dan teks yang menjadi media penghubungnya disebut hypertext (Yuhefizar, Mooduto, \& Hidayat, 2009). Website yang digunakan dalam pengabdian masyarakat ini dibangun menggunakan CMS. Content Management System (CMS) merupakan suatu sistem yang dipakai untuk proses pembuatan, proses pembaharuan, dan proses publikasi konten secara bersama (collaborative content management). Konten tersebut mengacu kepada informasi berupa teks, gambar, maupun format lain yang harus dikelola untuk mempermudah pembuatan, proses pembaharuan, distribusi, proses pencarian, analisis, dan untuk meningkatkan fleksibilitas yang akan ditransformasikan dalam bentuk yang lain. Terminologi CMS sebenarnya cukup luas, yaitu mencakup software aplikasi, DBMS, arsip, alur kerja, dan alat bantu lain yang dikelola sebagai bagian dari mekanisme jaringan informasi suatu perusahaan maupun global (Risdanto, 2014).

\section{Wordpress dan WooCommerce}

Wordpress pertama kali dirilis pada 27 Mei 2003 oleh pendirinya Matt Mullenweg bersama Mike Little. Pada September 2013, versi 3.6 telah di download lebih dari 6 juta kali. Dalam penggunaannya, Wordpress sangat tepat untuk kalangan profesional dengan memanfaatkan beberapa desain templet yang dapat di dowload dengan gratis maupun berbayar. Jika pengguna tidak memiliki domainnya sendiri, maka dapat memanfaatkan memanfaatkan sub domain secara gratis dari WordPress misalnya domainku.wordpress.com. WooCommerce adalah plugin Wordpress yang populer untuk membuat web e-commerce. Plug-in ini menyulap CMS WordPress menjadi platform e-commerce yang handal. WooCommerce memiliki berbagai fitur dan kemampuan karena berjalan di atas WordPress yang merupakan salah CMS terbaik. Hal ini tentu saja membuat WooCommerce sangat fleksibel dan mudah untuk disesuaikan (Oley, Sentinuwo, \& Sinsuw, 2016).

\section{Domain dan Hosting}

Domain adalah nama unik yang dimiliki oleh sebuah institusi sehingga bisa diakses melalui internet sedangkan hosting adalah tempat untuk menyimpan data-data dari sebuah website agar dapat diakses melalui internet, data-data tersebut dapat berupa file, gambar, video, email, database, program, dll. Hosting untuk keperluan website sering juga disebut sebagai Web Hosting. (Yuhefizar, Mooduto, \& Hidayat, 2009).

\section{Metode}

Pengabdian masyarakat ini dilaksanakan pada tanggal 1 sampai dengan 10 Maret tahun 2018 berlokasi di UD. Kusuma Jl. H. Mochamad Syahri 41 B RT. 03/02 Kel. Sindangjaya Kec. Mandalajati Kota Bandung. Adapun bentuk dari kegiatan ini adalah berupa pelatihan sistem penjualan online yang diikuti oleh pemilik dan 


\section{JURNAL ABDIMAS UBJ}

karyawan UD. Kusuma. Untuk mengetahui sejauh mana pemahaman peserta terhadap pelatihan yang telah disampaikan, pada akhir kegiatan dilakukan evaluasi berupa pengisian kuesioner oleh peserta.

\section{Metode Pengumpulan Data}

Metode pengumpulan data yang digunakan adalah studi pustaka, observasi, dan wawancara dengan lokasi objek pengabdian masyarakat yaitu UD. Kusuma Bandung untuk mendapatkan data-data proses pemasaran dan permasalahan yang ada di UD. Kusuma Bandung. Sumber pustaka diperoleh dari sumber person dan paper. Selain itu, data tentang produk yang ada di UD. Kusuma juga diperoleh berupa paper. Data paper diperoleh dari hasil studi pustaka dan observasi.

\section{Metode Pengembangan Sistem}

Perancangan web e-commerce ini di bangun menggunakan metode Waterfall. Adapun tahapan dalam pengembangan sistem informasi ini adalah sebagai berikut:

1. Analisa kebutuhan. Analisa kebutuhan merupakan tahapan awal dalam pengembangan website ini. Tahapan ini bertujuan untuk menentukan hal apa saja yang nantinya akan ditangani oleh website. Mulai dari konten, hak akses, pengguna, spesifikasi perangkat lunak/keras dan sebagainya.

2. Desain software dan website. Setelah mendapatkan hasil analisa kebutuhan pada tahapan sebelumya, berikutnya dilakukan desain website.

3. Implementasi. Untuk mengimplementasikan desain yang sudah dibuat pada tahapan sebelumnya, selanjutnya adalah implementasi dengan menggunakan web developing tools yang telah ditentukan yaitu Plugin WooCommerce pada CMS WordPress dan MySQL sebagai DBMS.

4. Pengujian. Sebelum proses perilisan website, pengujian dilakukan untuk memastikan bahwa website telah siap untuk digunakan. Pengujian yang digunakan adalah backbox testing dan kuesioner.

5. Pemeliharaan. Walaupun pemeliharaan dalam metode Waterfall berada pada tahapan akhir, namun cakupan implementasinya dapat dilakukan pada tahapan manapun. Tahapan ini sangat penting untuk memastikan website dapat bekerja sesuai dengan yang diharapkan dan untuk mencegah terjadinya kesalahan yang menyebabkan website mengalami gangguan.

\section{Hasil dan Pembahasan}

Tahap implementasi dilakukan dengan cara memberdayakan hardware dan software dalam merealisasikan hasil rancangan dengan cara melakukan instalasi dan coding atau pemrograman dengan tools yang sesuai yang telah dipersiapkan. Implementasi dilakukan dengan model sistem aplikasi lokal terlebih dahulu termasuk model pengujiannya sebelum dilakukan implementasi online yaitu dengan cara melakukan upload ke hosting. Persiapan implementasi localhost dilakukan instalasi kebutuhan sistem terlebih dahulu berupa pemenuhan instalasi hardware dan instalasi software 
sesuai spesifikasi. Instalasi software yang harus dipersiapkan adalah XAMPP yang berisi paket aplikasi program PHP, Database MySQL, dan webserver, Browser misalnya Mozilla Firefox, Notepad, CMS WordPress, dan Plugin WooCommerce (Diartono, Suhari, \& Supriyanto, 2015).

\section{Tampilan Antarmuka}

Tampilan utama website menggunakan browser desktop disajikan pada gambar 1 .

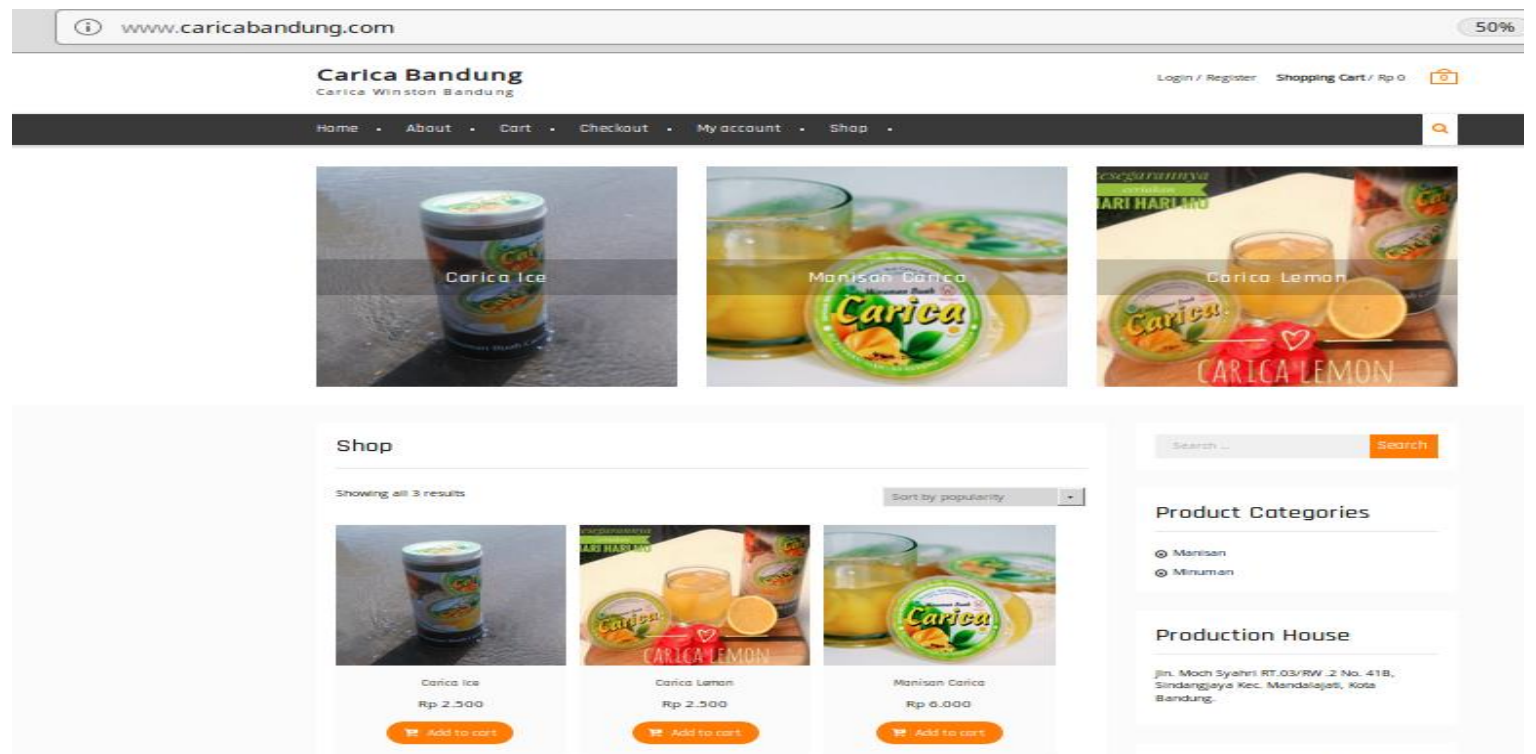

Gambar 1. Tampilan Utama Website menggunakan Browser Desktop

Suatu antarmuka harus memiliki karakteristik ragam dialog yang memberi kemudahan untuk dikenal dengan mudah oleh penggunanya atau biasa disebut Familiarity. Sehingga pada tampilan awal website ini memiliki tampilan yang mirip dengan tampilan web e-commerce pada umumnya (Firmansyah, 2016). Website yang telah berisi konten produk yang akan dijual sudah dapat diakses dengan cara memasukkan alamat URL http://www.caricabandung.com pada address bar browser. Tampilan utama website ditunjukkan oleh Gambar 1 di atas. Pada tampilan tersebut, terdapat beberapa menu yaitu Home, About, Cart, Checkout, My Account dan Wishlist. Pelanggan dapat langsung melakukan pembelian dengan cara klik "add to chart" dan melihat pesanannya pada menu chart. Selain menggunakan Browser Desktop, website ini juga telah memanfaatkan templet yang responsive sehingga mendukung tampilan pada perangkat mobile seperti pada gambar 2, gambar 3, gambar 4 dan gambar 5 berikut ini. 
JURNAL ABDIMAS UBJ

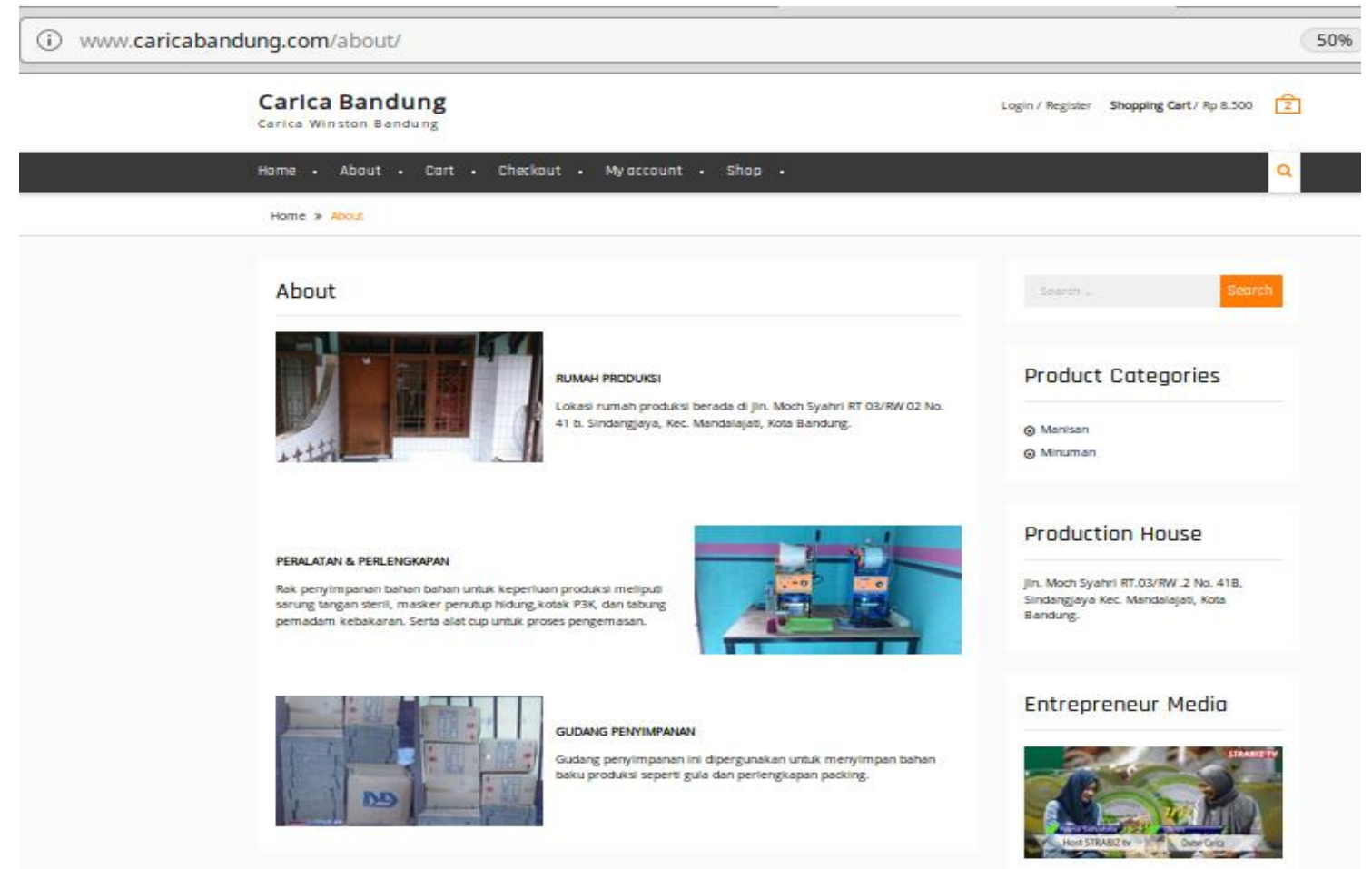

Gambar 2. Tampilan About

(i) www.caricabandung.com/cart/ $50 \%$

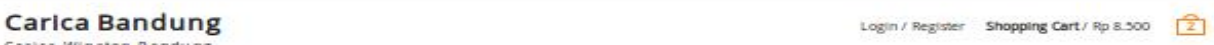

Hame - About - Cart - Checkout - Myaccount . Shap .

Hame $>$ cert

Cart

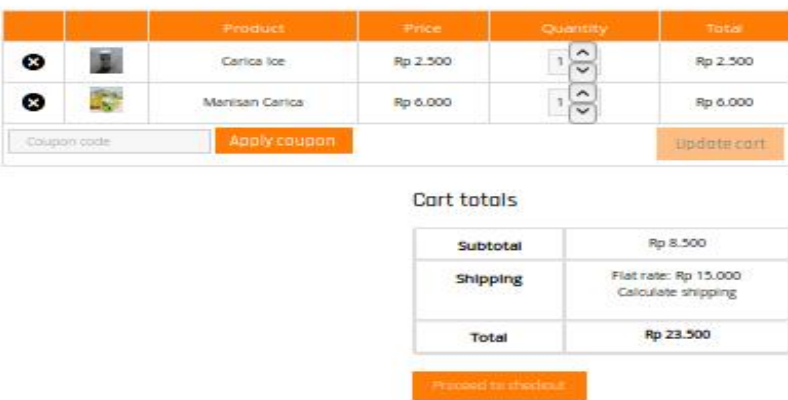

Product Categories

(1) Marison

(9) Minuman

Production House

Jin. Moch Syemrn RT O3/RW. 2 Na. 418 ,

Sindenzeysa kec Mardelojion, kosa

Bindongleys

Entrepreneur Medio

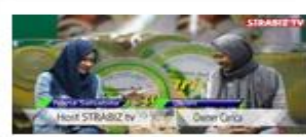

Gambar 3. Tampilan Chart 
JURNAL ABDIMAS UBJ

(i) I www.caricabandung.com/checkout/
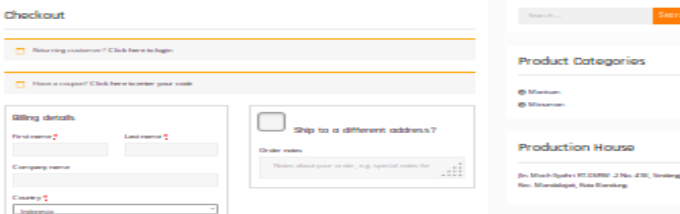

:…
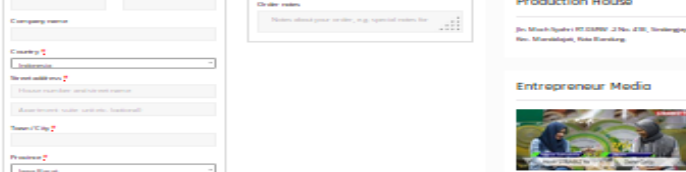

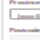
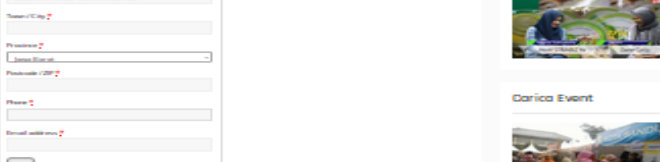

Strica Evern
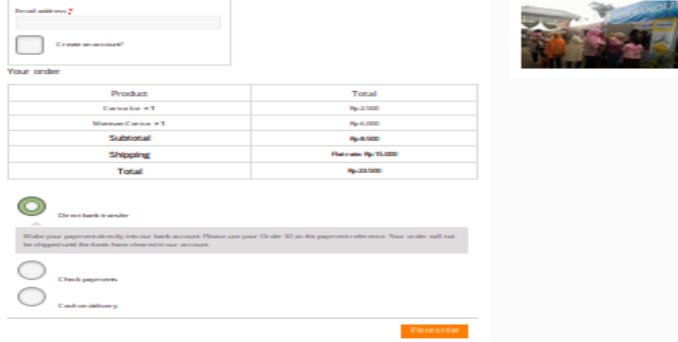

Gambar 4. Tampilan Checkout

(i) A www.caricabandung.com/my-account/

Carlca Bandung

Carica Winston Bandun

\section{$80 \% \mid \cdots \vee$ 战}

Login / Register Shopping Cart/Rp 0

Home 》 My account

My account

( $E R R O R$ : The password field is empty.

Login

Username or email address *

caricawinston@gmail.com

Password *

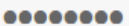

Login $\square$ Remember me

Lost your password?
Search

Product Categories

$\odot$ Manisan

๑ Minuman

Production House

In. Moch Syahri RT.03/RW . 2 No. 41B, Sindangjaya Kec. Mandalajati, Kota Bandung.

Gambar 5. Tampilan My Account 


\section{Pengujian}

\section{Blackbox Testing}

Pengujian blackbox dilakukan untuk mengetahui fungsionalitas website yang telah dibuat. Pengujian website ini dilakukan dengan metode pengujian blackbox yang fokus pada fungsional website yang telah dibuat, seperti pada tabel 1.

Tabel 1. Pengujian Black Box

\begin{tabular}{|l|l|c|}
\hline \multirow{2}{*}{ Fungsi } & \multicolumn{2}{|c|}{ Hasil } \\
\cline { 2 - 3 } & \multicolumn{1}{|c|}{ Diharapkan } & \multicolumn{1}{|c|}{ Pengujian } \\
\hline \hline Menu & Menampilkan menu utama & Sesuai \\
\hline About & $\begin{array}{l}\text { Menampilkan profil UD. } \\
\text { Kusuma }\end{array}$ & Sesuai \\
\hline Cart & $\begin{array}{l}\text { Menampilkan keranjang } \\
\text { belanja }\end{array}$ & Sesuai \\
\hline Checkout & $\begin{array}{l}\text { Menampilkan halaman } \\
\text { pembayaran }\end{array}$ & Sesuai \\
\hline My Account & $\begin{array}{l}\text { Menampilkan halaman login } \\
\text { pelanggan }\end{array}$ & \multicolumn{1}{|c|}{} \\
\hline
\end{tabular}

Sumber: Hasil Pengujian Black Box

\section{Kuesioner}

Sebagai pengujian public, dilakukan survey terhadap 10 (sepuluh) orang responden yang terdiri dari pemilik, karyawan dan masyarakat pengguna website UD. Kusuma ini. Survey ini dibuat dengan memanfaatkan fasilitas dari Google Form dan diberikan setelah responden diberikan tugas untuk mencoba mengakses website secara keseluruhan. Survey ini dilakukan untuk mengetahui tingkat penerimaan website oleh pengguna dan pemahaman pengguna dalam menggunakan website ini. Berikut ini adalah pertanyaan survey yang telah dilakukan:

1. Apakah proses pembelian produk melalui web ini mudah?

2. Apakah harga yang tertera pada saat checkout sudah sesuai?

3. Apakah navigasi web yang ditampilkan mudah dipahami?

4. Apakah kecepatan respon web baik?

5. Apakah informasi yang disampaikan web jelas?

6. Apakah penggunaan web ini dapat menghemat waktu?

7. Apakah web mudah digunakan?

8. Apakah tampilan dan warna pada web ini menarik?

9. Apakah tampilan awal pada web ini menarik?

10. Apakah secara keseluruhan web ini sudah baik?

Tabel 2 berikut adalah hasil dari survey yang sudah dilakukan terhadap 10 orang responden yang telah menggunakan website ini: 
Tabel 2. Hasil Kuesioner

\begin{tabular}{|c|c|c|c|c|}
\hline \multirow{2}{*}{ No. Pertanyaan } & \multicolumn{4}{|c|}{ Jawaban } \\
\cline { 2 - 5 } & SS & S & TS & STS \\
\hline 1 & 0 & 7 & 3 & 0 \\
\hline 2 & 1 & 8 & 1 & 0 \\
\hline 3 & 0 & 7 & 3 & 0 \\
\hline 4 & 0 & 8 & 2 & 0 \\
\hline 5 & 1 & 7 & 2 & 0 \\
\hline 6 & 0 & 9 & 1 & 0 \\
\hline 7 & 0 & 8 & 2 & 0 \\
\hline 8 & 1 & 6 & 3 & 0 \\
\hline 9 & 0 & 7 & 3 & 0 \\
\hline 10 & 0 & 8 & 2 & 0 \\
\hline$\%$ & 3 & 75 & $\mathbf{2 2}$ & $\mathbf{0}$ \\
\hline
\end{tabular}

Keterangan:
SS = Sangat Setuju
TS $\quad=$ Tidak Setuju
$\mathrm{S} \quad=$ Setuju
STS = Sangat Tidak Setuju

Berdasar pada tabel di atas, dapat dilihat bahwa sebanyak 75\% dari 10 orang responden menjawab setuju (S) yang dapat menyimpulkan bahwa Website ini memberikan kemudahan dan dapat membantu proses pemasaran produk UD. Kusuma secara online.

\section{Simpulan dan Rekomendasi}

Berdasarkan pembahasan di atas, dapat diambil beberapa kesimpulan diantaranya sebagai berikut:

a) Website E-Commerce UD. Kusuma telah berhasil dibuat

b) Website dibuat menggunakan CMS Wordpress dengan Plugin WooCommerce dan MySQL DBMS.

c) Website E-Commerce UD. Kusuma dapat diakses melalui alamat www.caricabandung.com. 


\section{JURNAL ABDIMAS UBJ}

Rekomendasi yang dapat diberikan:

a) Website yang telah dibuat masih terbilang sederhana, terutama dari segi tampilan, ada baiknya untuk pengembangan selanjutnya dapat dikembangkan lebih lanjut dengan tambahan informasi yang lebih lengkap sehingga dapat bermanfaat bagi pengelola dan pengguna website.

b) Perancangan website ini dapat dikembangkan menjadi lebih interaktif lagi sehingga informasi yang dibutuhkan pengguna mudah didapatkan dan lebih bermanfaat.

\section{Acknowledgements}

Terima kasih kepada Usaha Dagang (UD) Kusuma yang telah memfasilitasi kegiatan pengabdian kepada masyarakat yang dilaksanakan pada tanggal 1 sampai dengan 10 Maret 2018 bertempat di Jl. H. Mochamad Syahri 41 B RT. 03/02 Kel. Sindangjaya Kec. Mandalajati Kota Bandung.

\section{Daftar Pustaka}

Diartono, D. A., Suhari, Y., \& Supriyanto, A. (2015). Pengembangan Model CYBER CLUSTER E-COMMERCE Berbasis CMS dan SEO Produk UMKM . JCCS, Vol.9, No.2, July 2015, 145-156.

Firmansyah, R. (2016). EVALUASI HEURISTIK PADA DESAIN INTERFACE APLIKASI MY INDIHOME. Seminar Nasional Ilmu Pengetahuan dan Teknologi Komputer (pp. INF.69-INF.76). Jakarta: STMIK Nusa Mandiri Jakarta.

Firmansyah, R. (2018). Teknik Komputer dan Jaringan Dasar. Bandung: PT. Humaniora Utama Press.

Nimda. (2017, Februari 1). Apa itu E-Commerce? Retrieved April 19, 2018, from Universitas Pasundan | Perguruan Tinggi Terbaik di Indonesia: https:/ / www.unpas.ac.id/apa-itu-e-commerce/

Nuryanti. (2013). PERAN E-COMMERCE UNTUK MENINGKATKAN DAYA SAING USAHA KECIL DAN MENENGAH (UKM). JURNAL EKONOMI Volume 21, Nomor 4, 1-15.

Oley, E., Sentinuwo, S. R., \& Sinsuw, A. A. (2016). Sistem Pemesanan Makanan Dan Minuman Berbasis Website (Studi Kasus Taipan Restoran). E-Journal Teknik Elektro dan Komputer vol.5 no.5, 1-12.

Risdanto, B. (2014). PENGEMBANGAN E-LEARNING BERBASIS WEB MENGGUNAKAN CMS (CONTENT MANAGEMENT SYSTEM) WORDPRESS DI SMA NEGERI 1 KOTA MAGELANG. Yogyakarta: Universitas Negeri Yogyakarta. 
Sandy, K. (2016). Perancangan Online Smartphone Store Sebagai Peluang Menumbuhkan Usaha Mikro Kecil Menengah. Jurnal VOI STMIK Tasikmalaya Vol.5, No.1, 55-66.

Yuantari, M. C., Kurniadi, A., \& Ngatindriatun. (2016). PEMANFAATAN TEKNOLOGI INFORMASI UNTUK MENINGKATKAN PEMASARAN HASIL PERTANIAN DI DESA CURUT KECAMATAN PENAWANGAN KABUPATEN GROBOGAN JAWA TENGAH. Techno.COM, Vol. 15, No. 1, 4347.

Yuhefizar, Mooduto, H., \& Hidayat, R. (2009). CMM Website Interaktif MCMS Joomla (CMS). Jakarta: PT. Elex Media Komputindo. 